DOI https://doi.org/10.30525/978-9934-26-040-7-19

\title{
СТАН ПРИПИНЕННЯ ШЛЮБІВ В УКРАЇНІ ТА ЙОГО НАСЛІДКИ
}

\author{
Грицишина Л. В. \\ аспірант кафедри циивільного права та процесу \\ Хмельницького університету управління та права \\ імені Леоніда Юзькова \\ м. Хмельницький, Украӥна
}

Відповідно до ст. 21 Сімейного кодексу України, шлюбом є сімейний союз жінки та чоловіка, зареєстрований у органі державної реєстрації актів цивільного стану [1]. Сімейно-правовий інститут шлюбу, наслідки його укладення, припинення або визнання недійсним органічно пов'язані 3 головним соціально-правовим інститутом сім'єю. Необхідно погодитися 3 визначенням відомого науковця В. Ватраса про те, що «сьогодні широко вживаними $є$ поняття «сімейні правовідносини» та «шлюбно-сімейні правовідносини». Вважаємо, що обидва терміни можуть застосовуватись, але, якщо проаналізувати поняття «шлюбно-сімейні правовідносини», то на перший план виводиться інститут шлюбу як основна підстава виникнення сімейних правовідносин» [2, с. 45].

Друга половина XX ст. ознаменувалася для Європи, крім іншого, й так званим Другим демографічним переходом, у межах якого сформувалася загальноєвропейська тенденція зростання нестійкості шлюбних стосунків, внаслідок чого природно і закономірно підвищився рівень розірвань шлюбу шляхом розлучень. Підгрунтям виникнення та розвитку зазначеної тенденції стала трансформація моделі шлюбної та сімейної поведінки[3]. На цьому тлі Україна, на жаль, невигідно вирізняється, оскільки займає перше місце за кількістю розлучень серед європейських країн: за даними Держкомстату розривають шлюб 44,3 \% подружніх пар[4]. Однак, вітчизняні демографи, не заперечуючи плачевного стану та кризи інституту сім’ї в Україні, наголошують, що при здійсненні міжнародних порівнянь необхідно враховувати й те, що для нашої держави характерним $є$ й значно вищий рівень шлюбності в цілому. Відтак, за показником несталості шлюбу (співвідношення кількості зареєстрованих шлюбів і розлучень) Україна перебуває на середньоєвропейському рівні [3]. 
Проте, - у контексті оцінки виключно національного показника несталості шлюбу - офіційна статистика є невтішною (табл. 1).

Таблиця 1

Показник несталості шлюбу в Україні упродовж 2015-2019 рр.*

\begin{tabular}{|c|c|c|c|}
\hline Роки & $\begin{array}{c}\text { Кількість } \\
\text { заресстрованих } \\
\text { шлюбів, тис. }\end{array}$ & $\begin{array}{c}\text { Кількість } \\
\text { розлучень, тис. }\end{array}$ & $\begin{array}{c}\text { Показник } \\
\text { несталості } \\
\text { шлюбу, \% }\end{array}$ \\
\hline 2015 & 299 & 129,4 & 43,3 \\
\hline 2016 & 229,5 & 130 & 56,6 \\
\hline 2017 & 249 & 128 & 51,6 \\
\hline 2018 & 228 & 153 & 67 \\
\hline 2019 & 238 & 38,5 & 16,2 \\
\hline
\end{tabular}

*Примітка: Розроблено автором за джерелом[5].

Як видно із табл. 1, упродовж аналізованого періоду найвищий показник несталості шлюбу зафіксовано у 2018 р. (67\%), а найнижчий (усупереч прогнозів експертів) - у 2019 р. (16,2\%). Однак, радіти із цього приводу навряд чи можна, оскільки офіційна статистика щодо розірвання шлюбів, представлена Міністерством юстиції України, враховує лише кількість шлюбів, припинених в органах реєстрації цивільного стану громадян, але не кількісний показник шлюбів, розірваних через суд. Тобто, у даному разі ми оперуємо лише даними щодо розірвання шлюбів пар без дітей, пар, чиї діти на момент розлучення досягли повноліття або пар, у яких немає майнових суперечок. Таким чином, навіть такі загальні показники несталості шлюбу не можна вважати об'єктивними.

При цьому необхідно наголосити, що у розрізі тривалості шлюбу найменший відсоток розлучень припадає на пари, які проживають перший рік у шлюбі (біля 4\%), та на пари, тривалість шлюбу яких становить 20 і більше років (близько 12\%). Біля 30\% подружніх пар розпадається на 5-9 році шлюбу, що є цілком логічною тенденцією, оскільки саме на ці роки припадає так звана друга психологічна криза подружнього життя: пристрасть та сексуальний потяг уже не відіграють такої значної ролі для єдності подружжя, необхідність вирішення побутових питань та соціально-економічних проблем виснажує як фізично, так і емоційно обох партнерів, нерівномірний або й подекуди неправильний розподіл соціальних $\mathrm{i}$ гендерних ролей лягає непосильною ношею на одного із партнерів тощо. Унаслідок впливу 
цих факторів шлюб деформується, стає тягарем і зрештою - у більшості випадків - руйнується.

Для суспільства в цілому, наслідки розірвання шлюбу $є$, умовно кажучи, монохарактерними, тобто, їх зміст та сутність можна представити в межах одного вектору - соціально-демографічного. Так, наслідками розлучень сьогодні в Україні є: утворення неповних сімей, адже понад $80 \%$ розлучених $\epsilon$ однодітними або бездітними подружжями, небажання вступати у повторний шлюб. Нерідко після розлучення батько i/чи мати намагаються налагодити своє особисте життя, покидаючи дитину чи дітей напризволяще або доручаючи їхнє виховання бабусям та дідусям. Інколи діти стають соціальними сиротами внаслідок того, що після розлучення той із батьків, із ким залишилися діти, намагаючись максимально забезпечити себе та дітей, постійно і важко працює, і нерідко за межами країни.

У той же час, індивідуальні наслідки розірвання шлюбу шляхом розлучення, не $\epsilon$ такими односпрямованими, а тому дозволимо собі розподілити їх на групи, обравши в якості класифікаційного критерію їх характер.

Нам уявляється, що найбільш доцільно класифікувати наслідки розлучення для індивіда на групи правового, економічного, суспільного, біолого-фізіологічного та психіко-психологічного характеру.

Загальновідомо, що припинення шлюбу завжди породжує настання певних правових наслідків майнового та немайнового характеру як для колишнього подружжя, так і інших осіб. Правові наслідки розірвання шлюбу дістають вияв у припиненні особистих і майнових прав колишнього подружжя. При чому, одні права припиняються відразу після розлучення, а інші можуть бути збережені або за бажанням одного з подружжя (наприклад, право на вибір прізвища), або в силу прямого припису закону. Так, відповідно до ч. 2 ст. 76 СК України непрацездатна особа, яка потребує матеріальної допомоги, зберігає право на одержання утримання від колишнього чоловіка, колишньої дружини, якщо вона стала непрацездатною до розірвання шлюбу або протягом одного року від дня розлучення [1].

3 розірванням шлюбу припиняється дія законного режиму майна подружжя, тобто режиму їх спільної сумісної власності, щоправда, за умови поділу майна, набутого дружиною і чоловіком за час шлюбу. Після розірвання шлюбу припиняються й права, передбачені іншими галузями права, зокрема право на одержання одним із колишнього подружжя спадщини після смерті другого 3 них, право на пенсійне забезпечення у зв'язку з втратою годувальника тощо. Однак розірвання 
шлюбу, що припиняє правовідносини між подружжям, не призводить до припинення правовідносин між батьками й дітьми.

До групи економічних наслідків можна віднести скорочення сімейного бюджету (якщо розлучення відбулось 3 інших причин, ніж економічне насилля або неналежне матеріальне забезпечення одним із подружжя сім'ї), погіршення житлових умов, неможливість задоволення цілого ряду базових елементарних життєвих потреб тощо.

Хоча, з іншого боку, економічні наслідки можуть виражатися як додаткові витрати для того із подружжя, на кого у законодавчо визначеному порядку покладено обов'язок утримання іншого або виплати аліментів на утримання дитини. Крім того, економічні наслідки розлучення настають і $\epsilon$ доволі відчутними при розподілі спільного майна подружжя, особливо, якщо це майно має значну вартість та $€$ доволі цінним і перспективним.

Суспільні наслідки розлучення охоплюють такий спектр наслідків, як соціальна ізоляція - на культурні заходи чи розваги не вистачає часу й грошей, а сім'ї, з якими дружило подружжя, поступово віддаляються.

Крім іншого, розлучення провокує настання таких індивідуальних наслідків, як біолого-фізіологічні. Дослідження свідчать, що у розлучених осіб вище ризик передчасної смерті порівняно з тими, хто перебуває у шлюбі [3, с. 84], а упродовж року після розлучення ризик захворювань психічними й шкірними захворюваннями, сечостатевими розладами, головним болем у розлученого подружжя збільшується на $30 \%$.

До того ж, наслідки розлучення відчувають на собі не лише дорослі члени сім'ї, але й діти, оскільки розлучення батьків негативно впливає на формування особистості дитини, що зумовлено переживаннями гніву, почуття провини і страху. Часто у дітей виникають психосоматичні розлади: біль у шлунку, безсоння, головні болі.

Не менш руйнівними для подружжя $є$ i психіко-психологічні наслідки розлучень, оскільки при розлученні в обох партнерів знижується самооцінка, що призводить до виникнення цілого ряду особистісних і міжособистісних проблем [5].

Разом $з$ тим, ні сімейне законодавство України, ні доктрина права не містять на сьогоднішній день чіткого визначення поняття «розірвання шлюбу». У більшості джерел увага звертається лише на той факт, що розірвання шлюбу $\epsilon$ різновидом припинення шлюбу за життя подружжя, у зв'язку з чим виникає необхідність на законодавчому рівні чіткого визначення цього поняття, яке дозволяло би зрозуміти його сутність, а також створити на рівні держави систему соціальних інституцій, покликаних мінімізувати негативні наслідки розлучень для усіх осіб, втягнутих в цей процес. 


\title{
Література:
}

1. Сімейний кодекс України від 10.01.2002 р. № 2947-III. Верховна Рада Украйни. Законодавство України. URL: https://zakon.rada.gov.ua/ laws/show/2947-14.

2. Ватрас В.А. Суб'єкти сімейних правовідносин. дис ... канд. юрид. наук: 12.00.03 . К., 2008. 227 с.

3. Слюсар Л.І. Розлучення в Україні в демографічному вимірі: минуле і сучасність. Демографія та соціальна економіка. 2014. № 2 (22). C. $78-89$.

4. В Україні замовчують катастрофу розлучень. Всеукраїнський Собор. URL: https://sobor.com.ua/news/v-ukrayinizamovchuyut-katastrofu-rozluchen.

5. Максимова Н.Ю. Розлучення батьків як фактор девіантної поведінки дітей. URL: http://lib.iitta.gov.ua/705179/1/ Максимова_H.Ю.PDF

DOI https://doi.org/10.30525/978-9934-26-040-7-20

\section{ПРАВОВЕ РЕГУЛЮВАННЯ САМОПРЕДСТАВНИЦТВА ЮРИДИЧНИХ ОСІБ}

\author{
Кондрат'єва Л. А. \\ кандидат юридичних наук, \\ дочент кафедри процесуального права юридичного факультету \\ Чернівецького національного університету імені Юрія Федьковича \\ м. Чернівиі, Украӥна
}

В 2016 році Верховна РадаУкраїни внесла зміни до Конституції України, згідно з якими було введено так звану «адвокатську монополію». Ці зміни передбачали здійснення представництва в судах виключно адвокатами, за винятком справ, перелічених в статті 131-2 Конституції України [1]. Як бачимо, Конституція України закріплює виключне право адвокатів на представництво інтересів особи в суді. Водночас фізичні та юридичні особи можуть представляти себе в суді самостійно. Поняття «самопредставництво» закріплене в процесуальних кодексах: у ЦПК (ст. 58) [2 ]; ГПК (ст. 56) [ 3 ]; КАС (ст. 55) [4]. Аналізуючи вказані процесуальні норми, можна стверджувати, що 